\title{
THE PATTERN OF WATER CONSUMPTION DURING RAMADHAN AND SHORT-TERM MEMORY AMONG ADOLESCENTS
}

\author{
Zahrotun Nihayah ${ }^{1}$, Ratri Ciptaningtyas ${ }^{2}$ and Catur Rosidati ${ }^{3}$ \\ \{zahrotun.nihayah@gmail.com ${ }^{1}$, ratri.ciptaningtyas@uinjkt.ac.id ${ }^{2}$,rosidati@gmail.com ${ }^{3}$ \}
}

Faculty of Psychology ${ }^{1}$ and Faculty of Health Science ${ }^{23}$ Syarif Hidayatullah State Islamic

University Jakarta, Indonesia

\begin{abstract}
The purpose of this study is to determine the relationship between the patterns of the water consumptions and short-term memory in adolescents during fasting and not fasting. The design of this study is cross-sectional and was conducted from 18 July to 31 October 2013. The research was conducted by giving questionnaires to the students of MAN 6 East Jakarta, medicine and health science and psychology faculty students of Syarif Hidayatullah State Islamic University. The results showed that there is no significant relationship between the patterns of the water consumptions and memory. The aspects of intentions and beliefs of fasting was suspected as the force underlied the fasting behavior, thus although respondents were dehydrated, it will not disrupt the cognitive function, especially the short-term memory. This study showed that fasting is beneficial to health if done with a full spirit of fasting.
\end{abstract}

Keywords: Adolescents, fasting, the patterns of water consumptions, dehydration, short-term memory

\section{Introduction}

\subsection{Background}

In general, experts consider memory as the connection between experiences and the past. What is remembered is what has been experienced, perceived, inserted and stored into their minds, thus later the event will be recalled in consciousness. Memory is a cognitive function that involves the brainwork in taking informations, which will be studied more deeply in cognitive psychology and neuroscience. The structure of memory can be divided into three systems, namely: (a) sensory memory system; (b) short-term memory system; and (c) long-term memory system.

The cognitive function is one of the most important aspects for adolescents, which is related to their academic achievements at school. One of the cognitive functions is the short-term memory that records informations obtained during a certain time, but not for a long time. Thus, when learned things, there is a process of informations storing in the lobe of the brain. Short-term memory can be improved, not only through a series of learning stimulus, but also, from the medical perspective, the brain's composition is mostly water [1] that maintaining hydration status is essential for brain cells to function properly.

Within the Balanced Nutrition Guidelines of Indonesia it is said that a human being should consume enough clean and safe water [2]. The benefits and potentials of water have been mentioned in the Holy Qur'an. It stated that water is the source of life. The lack of water will stop the entire system of world life. 
"Have those who disbelieved not considered that the heavens and the earth were a joined entity, and We separated them and made from water every living thing? Then will they not believe?" (AlAnbiyaa 21: 30).

Water is very important as the body is extremely dependent on it during the biological process. That is why Rasulullah SAW encouraged his people to sahūr and iftar immediately, though only by drinking water. Although drinking water is a small matter, Islam is different from other religions, it teaches adab and etiquette that no other religion has.

Rasulullah SAW decreed that, "If any of you are going to eat, eat with your right hand. And if you are going to drink, drink with your right hand. Indeed, Satan eats with its left hand and drinks with its left hand." (HR Muslim).

Water is included as the major and fundamental component in the cone of balanced nutrition as the embodiment of the Balanced Nutritional Guidelines. One of the reasons that make water as the major and fundamental component in the cone of balanced nutrition is that the problem of dehydration is quite substantial and had a negative impact if neglected [3]. Dehydration occurs when the water output is hypotonic fluid, i.e. the volume of water that came out is much larger than the amount of sodium did [4]. The mild dehydration $(<5 \%)$ was caused by pathogenic factor in oligohydramnios, prolonged labor and hypertonic dehydration. If the condition continues chronically, it is a pathogenic factor in urolithiasis, urinary tract infections, constipation, hypertension, venous thromboembolism, coronary heart disease, stroke, diabetic ketoacidosis, gallstones and glaucoma [5]. Study that used a combination of high temperatures and exercise was conducted to induce the state of dehydration in healthy adult males.

When the dehydration level reached $2 \%$ or more, damage occurs to the cognition function, especially short-term memory, reasoning and coordination between hands and eyes. Based on the study, it is known that the indication of impaired cognitive function has occurred at dehydration level of $1 \%$ [6]. The human brain is the central structure setting that has a volume of about $1350 \mathrm{cc}$ and consists of 100 million nerve cells or neurons. The human brain is responsible for the control of the whole body and mind of a human. Hence, the human brain and mind are closely related [7]. Recent study shows that in adolescents the brain continues to experience the process of development, not only in the first year of a child's life. The areas of an adolescent's brain development include planning, decision making, cognition, and logic [8]. In the context of school academic achievement, cognition has an important role [9], as adolescents with a good cognitive ability will also have a good achievements as well. Memory is known as an important matter in the study of cognitive psychology. Memory is the ability or process that involves the role of importing (learning), storing, and recalling things that have been experienced or learned [10].

Some adolescents still consume less water than their needs. The Indonesian Hydration Regional Study (THIRST) revealed that $46.1 \%$ of subjects in the study suffered the lack of water. This incidence was higher in adolescents $(49.5 \%)$ than in adults (42.5\%) [11]. The survey did not look at the relationship between dehydration and memory, in fact, there are still very few studies examining the relationship between the two [12]. Whereas memory, particularly short-term memory, is most susceptible to dehydration.

Fasting or shiyam by language means "to refrain from something, leave something, and prevent something", which means silent, prevent and resist to not speak [13].

Fasting in Arabic is shaum or shiyam, which both means al-imsak, i.e. refrain from something mubah (allowed), in the form of lust towards food and sexual, which aims to get closer to the God [14].

Fasting according to Syara', means refrain self from things that might break the intention of someone in the daytime, since dawn to sunset. In other words, fasting is to refrain from deeds 
in the form of two kinds of lust (lust towards food and sexual) and from any other things to not be consumed, such as drugs and the like, which was started since Fajr until sunset [15].

In terms of Syar'i, fasting means refraining from things that break the fast as eating, drinking, sexual intercourse, istima' (stimulates the release of semen deliberately, either by making out with their own spouse without any sexual intercourse or stimulate the genitals with hands and other tools), or stimulates vomit deliberately from the time of Fajr until Maghrib [14].

Meanwhile, in term of Shari'a, fasting means "refrain self from eating, drinking and having sexual intercourse with their spouse, from Fajr to Maghrib, to seek Allah SWT's pleasure (Ridha) and virtue towards Allah SWT (Taqwa), by following the path of the God and educating self of God's will [16].

A mandatory requirement for a person to fast are they are a Muslim, sensibly normal (not mentally ill or have a normal growth of intelligence, enable them to distinguish between the good and the bad), has reached the sexual maturity (puberty), physically healthy, capable to fast, not a traveler (Musafir), and for women to not in some specific circumstances (such as menstruating or in a childbed condition) [16].

During Ramadhan, the opportunity to drink water is limited only at night, which is from sunset to dawn. If a person didn't know the required amount of water to be consumed, mild dehydration might occure during the month of fasting. Based on the study that conducted in Jakarta, as one of the lowland and hot plains, and in West Bandung, which is a highland and cool plains, shows that more than half of adolescent subjects have dry lips during Ramadhan, and about one-third among adult subjects. This incidence is higher in subjects that live in hot plains or lowland than in cool plains or highland [17]. One of the cause of dry lips is the lack of water consumption. The required amount of water to be consumed in order to live healthily and actively every day depends on the body size, age, types of daily activities and ambient temperature. Until now, there has been no study conducted on the pattern of the water consumption during fasting [4].

\subsection{The Core Issues}

In the context of school academic achievement, memory, as a part of cognition, has an important role, because one aspect of achievement is memory. One of the organs that contains water in such a large quantity is the brain, which is about $70 \%$. When it reaches the dehydration level of $2 \%$ or more, it might damage the cognitive function, especially short-term memory, reasoning, and the coordination between hands and eyes. Based on the study, the indication of the cognitive function deterioration has even occurred at the dehydration level of $1 \%$. However, some adolescents still consume less water than required. The Indonesian Hydration Regional Study (THIRST) revealed that $46.1 \%$ of subjects in the study suffered the lack of water. This incidence was higher in adolescents $(49.5 \%)$ than in adults $(42.5 \%)$. The survey did not look at the relationship between dehydration and memory, in fact, there are still very few studies examining the relationship between the two. Based on the study that conducted in Jakarta, as one of the lowland and hot plains, and in West Bandung, which is a highland and cool plains, shows that more than half of adolescent subjects have dry lips during Ramadhan, and about one-third among adult subjects. This incidence is higher in subjects that live in hot plains or lowland than in cool plains or highland. One of the cause of dry lips is the lack of water consumption. Until now, there has been no study conducted on the pattern of the water consumption during fasting, but knowing the pattern of the water consumption during fasting can prevent dehydration, and also ultimately reduce the risk of short-term memory loss, thus the concentration during studying will not be disturbed.

\subsection{Purpose}


The purpose of this study is to determine the relationship between dehydration and short-term memory in adolescents during fasting and not fasting.

\section{Methods}

The design of this study is cross-sectional, in which the researchers measured the independent and dependent variable at the same time. The study was conducted from 18 July to 31 October 2013. The research was conducted by giving questionnaires to the students of MAN 6 East Jakarta. In this study, the instrument used is questionnaires forms to be filled by students. The questions posed was the identity (name, place and date of birth, gender, address, phone number), afterwards, the students answered the measurement instrument of memory, the dehydration level was measured by Urine Density, and water consumption was measured by 1 day food recall, while the memory measurement was done by using the instrument. Short-term memory was measured by Standard Progressive Matrices and Advanced Progressive Matrices test.

Simultaneous memory measurements, urine sample collecting, and water consumption assessment were conducted to the entire sample group by 1 day food recall. The data was collected on the second week of Ramadhan and the second week after Eid Al-Fitr.

Data analysis was done by univariate and bivariate analysis by using data analysis software. The result of univariate analyses are the description of respondents' condition based on each variables which will be presented in table and graph forms. Bivariate analysis was done by using Chi Square statistical test to determine the relationship and the significance of dehydration status when fasting and not fasting, with the significance level of 5\%. Further test was done by measuring dehydration as the mediator variable between gender, the patterns of water consumption, physical activity, and memory using AMOS software.

\section{Results and Discussion}

Out of 100 samples planned to be the subject of research at MAN 6, only 40 samples meet the APM, IST and food consumption assessment instruments during fasting and not fasting, which means the response rate obtained is low (40\%). To complete the minimum sample size, samples were added from students of medicine and health science and psychology faculty Syarif Hidayatullah State Islamic University still classified as adolescents and agreed to fast when questionnaires were given, also when measurements and urine collecting were conducted. The numbers of sample from University are 52 samples, thus the overall number of samples in this study are 92 samples.

\subsection{Characteristics of Respondents}

This research was conducted at different times, i.e. when fasting and not fasting, which was with the same respondent. Based on this matter, it is possible that the characteristics of respondents will be different when fasting and not fasting. Therefore, the characteristics of the respondents are distinguished as in table 1 below. 
Table 1: The Mean Distribution of Respondents Based on Gender, water consumption, physical activity, body mass index, Urine Density, and IST and APM Score when fasting and not fasting

\begin{tabular}{|l|l|l|l|l|}
\hline \multirow{2}{*}{} & \multicolumn{2}{|l|}{ Fasting $(\mathrm{n}=92)$} & \multicolumn{2}{l|}{ Not Fasting $(\mathrm{n}=92)$} \\
\cline { 2 - 5 } & $\begin{array}{l}\text { Male } \\
\mathrm{N}=35\end{array}$ & $\begin{array}{l}\text { Female } \\
\mathrm{N}=57\end{array}$ & $\begin{array}{l}\text { Male } \\
\mathrm{N}=35\end{array}$ & $\begin{array}{l}\text { Female } \\
\mathrm{N}=57\end{array}$ \\
\hline $\begin{array}{l}\text { Water } \\
\text { Consumption }\end{array}$ & 1578,0 & 1399,1 & 1158,8 & 1325,3 \\
\hline $\begin{array}{l}\text { Physical } \\
\text { Activities }\end{array}$ & 2,16 & 2,03 & 2,48 & 2,29 \\
\hline $\begin{array}{l}\text { Body Mass } \\
\text { Index }\end{array}$ & 19,69 & 21,33 & 20,99 & 20,53 \\
\hline \begin{tabular}{l} 
Urine Density \\
\hline
\end{tabular} & 1,015 & 1,018 & 1,014 & 1,013 \\
\hline APM Score & 10,86 & 10,26 & 10,28 & 11,03 \\
\hline IST Score & 106,09 & 106,56 & 111,43 & 110,35 \\
\hline
\end{tabular}

Based on table 1, it is known that there are more female respondents than men, which is 57 respondents. In both sexes the averages of ITS Score, urine density, and physical activity was higher when not fasting if compared with the averages when fasting. Furthermore, it is known that within male respondents, the average of water consumption at the time of fasting is higher than when not fasting, which is $1578 \mathrm{ml}$.

\subsection{The Univariate Analysis of Water Consumption, Physical Activity, Body Mass Index, Urine Density, and APM and IST Score when Fasting and Not Fasting}

Univariate analysis in this study using categorization as presented in table 2.

Table 2: Univariate Analysis of Water Consumption, Physical Activity, Body Mass Index, Urine Density, and APM and IST Score When Fasting and Not Fasting

\begin{tabular}{|l|l|l|l|l|}
\hline \multirow{2}{*}{ Water Consumption } & \multicolumn{2}{|l|}{ Fasting (n=92) } & \multicolumn{2}{l|}{ Not Fasting (n=92) } \\
\cline { 2 - 5 } & $\mathrm{N}$ & $\%$ & $\mathrm{~N}$ & $\%$ \\
\hline a. $<$ mean & 40 & $43,5 \%$ & 36 & $39,1 \%$ \\
\hline Water Consumption & \multicolumn{2}{|l|}{ Fasting (n=92) } & \multicolumn{2}{l|}{ Not Fasting (n=92) } \\
\cline { 2 - 5 } & $\mathrm{N}$ & $\%$ & $\mathrm{~N}$ & $\%$ \\
\hline b. $\geq$ mean & 52 & $56,5 \%$ & 56 & $60,9 \%$ \\
\hline
\end{tabular}




\begin{tabular}{|c|c|c|c|c|}
\hline \multicolumn{5}{|l|}{ Physical Activities } \\
\hline a. $<$ mean & 53 & $57,6 \%$ & 52 & $56,5 \%$ \\
\hline b. $\geq$ mean & 39 & $42,4 \%$ & 40 & $43,5 \%$ \\
\hline \multicolumn{5}{|l|}{ Body Mass Index } \\
\hline a. Risk & 33 & $35,9 \%$ & 24 & $26,1 \%$ \\
\hline b. Not Risk & 59 & $64,1 \%$ & 68 & $73,9 \%$ \\
\hline \multicolumn{5}{|l|}{ Urine Density } \\
\hline $\begin{array}{l}\text { Severe dehydration } \\
\text { level }\end{array}$ & 13 & $14,1 \%$ & 3 & $3,3 \%$ \\
\hline $\begin{array}{l}\text { Mild dehydration } \\
\text { level }\end{array}$ & 19 & $20,7 \%$ & 13 & $14,1 \%$ \\
\hline c. Well hydrated & 60 & $65,2 \%$ & 76 & $82,6 \%$ \\
\hline \multicolumn{5}{|l|}{ APM Score } \\
\hline a. $<$ mean & 42 & $45,7 \%$ & 40 & $43,5 \%$ \\
\hline b. $\geq$ mean & 50 & $54,3 \%$ & 52 & $56,5 \%$ \\
\hline \multicolumn{5}{|l|}{ IST Score } \\
\hline a. $<$ mean & 44 & $47,8 \%$ & 29 & $31,5 \%$ \\
\hline b. $\geq$ mean & 48 & $52,2 \%$ & 63 & $68,5 \%$ \\
\hline
\end{tabular}

Based on table 2, it is known that the percentage of water consumption at the time not fasting is higher if compared with the average when fasting, which is $60.9 \%$. At the time of fasting condition, the percentage of APM score and physical activity was not much different compared to not fasting condition. Contrarily, the percentage of IST score was higher at the time of not fasting, which is $68.5 \%$, and was higher than the average. Likewise, the percentage of urine density that is well hydrated higher at the time of not fasting $(82.6 \%)$ compared to the average when fasting $(65.2 \%)$.

\subsection{Relationship between Gender, Water Consumption, Physical Activity, Body Mass Index and Urine Density When Fasting and Not Fasting}

The relationship between gender, water consumption, physical activity, body mass index and urine density when fasting and not fasting was Based on Table 3 of 92 respondents, it is known that women are more dehydrated than men, whether when fasting and not fasting. Women also had severe dehydration of $17.5 \%$ and a mild dehydration of $22.8 \%$ at the time of fasting. When determined by using Chi-Square statistical test, as the results are presented in Table 3 below. 
Table 3: Relationship between Gender, Water Consumption, Physical Activity, Body Mass Index and Urine Density When Fasting and Not Fasting

\begin{tabular}{|c|c|c|c|c|c|c|c|c|}
\hline & \multicolumn{4}{|c|}{ Fasting $(\mathrm{n}=92)$} & \multicolumn{4}{|c|}{ Not Fasting $(\mathrm{n}=92)$} \\
\hline & $\begin{array}{l}\text { Severe } \\
\text { dehydration } \\
(\%)\end{array}$ & $\begin{array}{l}\text { Mild } \\
\text { dehydration } \\
(\%)\end{array}$ & $\begin{array}{l}\text { Well } \\
\text { hydrated } \\
(\%)\end{array}$ & $\begin{array}{l}\mathrm{P} \\
\text { Value }\end{array}$ & $\begin{array}{l}\text { Severe } \\
\text { dehydration } \\
(\%)\end{array}$ & $\begin{array}{l}\text { Mild } \\
\text { dehydration } \\
(\%)\end{array}$ & $\begin{array}{l}\text { Well } \\
\text { hydrated } \\
(\%)\end{array}$ & $\begin{array}{l}\mathrm{P} \\
\text { Value }\end{array}$ \\
\hline \multicolumn{9}{|l|}{ Gender } \\
\hline $\begin{array}{l}\text { a. Male } \\
\text { b. } \\
\text { Female }\end{array}$ & $\begin{array}{l}8,6 \\
17,5\end{array}$ & $\begin{array}{l}17,1 \\
22,8\end{array}$ & $\begin{array}{l}74,3 \\
59,6\end{array}$ & 0,319 & $\begin{array}{l}5,4 \\
0\end{array}$ & $\begin{array}{l}10,7 \\
19,4\end{array}$ & $\begin{array}{l}56 \\
36 \\
\end{array}$ & 0,208 \\
\hline \multicolumn{9}{|c|}{ Water Consumption } \\
\hline $\begin{array}{l}\text { a. }< \\
\text { mean } \\
\text { b. } \geq \\
\text { mean }\end{array}$ & $\begin{array}{l}11,5 \\
11,75\end{array}$ & $\begin{array}{l}23,1 \\
17,5\end{array}$ & $\begin{array}{l}65,4 \\
65\end{array}$ & 0,681 & $\begin{array}{l}0 \\
4,4\end{array}$ & $\begin{array}{l}16,7 \\
13,2\end{array}$ & $\begin{array}{l}83,3 \\
82,4\end{array}$ & 0,546 \\
\hline \multicolumn{9}{|c|}{ Body mass index } \\
\hline $\begin{array}{l}\text { a. risk } \\
\text { b. not } \\
\text { risk }\end{array}$ & $\begin{array}{l}18,2 \\
11,9\end{array}$ & $\begin{array}{l}18,2 \\
22\end{array}$ & $\begin{array}{l}63,6 \\
66,1\end{array}$ & 0,681 & $\begin{array}{l}1,8 \\
5,7\end{array}$ & $\begin{array}{l}14 \\
14,3\end{array}$ & $\begin{array}{l}84,2 \\
80\end{array}$ & 0,580 \\
\hline \multicolumn{9}{|c|}{ Physical activity } \\
\hline $\begin{array}{l}\text { a. }< \\
\text { mean } \\
\text { b. } \geq \\
\text { mean }\end{array}$ & $\begin{array}{l}22,6 \\
2,6\end{array}$ & $\begin{array}{l}20,8 \\
20,5\end{array}$ & $\begin{array}{l}56,6 \\
76,9\end{array}$ & 0,020 & $\begin{array}{l}1,9 \\
5\end{array}$ & $\begin{array}{l}15,4 \\
12,5\end{array}$ & $\begin{array}{l}82,7 \\
82,5\end{array}$ & 0,674 \\
\hline
\end{tabular}

Fasting, women also had mild dehydration of $19.4 \%$. At the time of not fasting, most of respondents at the level of well hydrated in both gender categories, which are $83.3 \%$ and $82.4 \%$. Respondents with less than average water consumption at the time of fasting were dehydrated at $11.5 \%$, on the other hand, none had severe dehydration when not fasting. With more physical activity than average, dehydration occurs more frequently during fasting compared than when not fasting, with the severe dehydration percentage of $2.6 \%$ and mild dehydration of $20.5 \%$.

Of all variables analyzed statistically, it is known that the $\mathrm{p}$ value for physical activity is 0,002 . With the $\mathrm{p}$ value $<\alpha(5 \%)$ it can be concluded that there is a significant relationship between physical activity at the time of fasting and urine density.

3.4. Relationship between Gender, Water Consumption, Physical Activity, Body Mass Index, and Urine Density and APM and IST Score When Fasting and Not Fasting

Bivariate analysis was done by using Chi-Square statistical test to determine the relationship between gender, water consumption, physical activity, body mass index, and urine density and APM and IST scores during fasting and not fasting which are presented in table 4 and 5. 
Table 4: Relationship between Gender, Water Consumption, Physical Activity, Body Mass Index, and Urine Density and APM Score When Fasting and Not Fasting

\begin{tabular}{|c|c|c|c|c|c|c|}
\hline & \multicolumn{3}{|c|}{ Fasting $(\mathrm{n}=92)$} & \multicolumn{3}{|c|}{ Not Fasting $(\mathrm{n}=92)$} \\
\hline & $<$ mean & $\geq$ mean & P Value & $<$ mean & $\geq$ mean & P Value \\
\hline \multicolumn{7}{|l|}{ Gender } \\
\hline a. Male & 49,1 & 50,9 & \multirow{2}{*}{0,850} & 40,4 & 59,6 & \multirow{2}{*}{0,578} \\
\hline b. Female & 40 & 60 & & 48,6 & 51,4 & \\
\hline \multicolumn{7}{|l|}{ Water Consumption } \\
\hline a. $<$ mean & 48,1 & 51,9 & \multirow{2}{*}{0,748} & 42,9 & 57,1 & \multirow{2}{*}{1.000} \\
\hline b. $\geq$ mean & 42,5 & 57,5 & & 44,4 & 55,6 & \\
\hline \multicolumn{7}{|l|}{ Body Mass Index } \\
\hline a. Risk & 48,5 & 51,5 & \multirow{2}{*}{0,683} & 41,7 & 58,3 & \multirow{2}{*}{1.000} \\
\hline b. Not Risk & 44,1 & 55,9 & & 44,1 & 55,9 & \\
\hline \multicolumn{7}{|l|}{ Physical Activity } \\
\hline a. $<$ mean & 56,6 & 43,4 & \multirow{2}{*}{0,025} & 42,3 & 57,7 & \multirow{2}{*}{0,963} \\
\hline b. $\geq$ mean & 30,8 & 69,2 & & 45 & 55 & \\
\hline \multicolumn{7}{|l|}{ Urine Density } \\
\hline a. Several Dehydration & 84,6 & 15,4 & \multirow{3}{*}{0,009} & 33,3 & 66,7 & \multirow{3}{*}{0,857} \\
\hline b. Mild Dehydration & 42,1 & 57,9 & & 38,5 & 61,5 & \\
\hline c. Well Hydrated & 38,3 & 61,7 & & 44,7 & 55,3 & \\
\hline
\end{tabular}

Based on table 4, it is known that respondents which had urine density with severe dehydration when fasting had the APM score below average, which are higher $(84.6 \%)$ compared to when not fasting (33.3\%). Within women respondents, the APM score were above the average and higher than men at the time of fasting $(60 \%)$, and at the time of not fasting the APM score still is above the average and higher in men $(59.65 \%)$.

Of all of variables analyzed statistically, it is known that the $p$ value for urine density is 0,009 and $p$ value for physical activity is 0.025 . With the $p$ value $<\alpha(5 \%)$ it can be concluded that there is a significant relationship between urine density and physical activity when fasting and APM score. 
Table 5: Relationship between Gender, Water Consumption, Physical Activity, Body Mass Index and Urine Density and IST Score When Fasting and Not Fasting

\begin{tabular}{|c|c|c|c|c|c|c|}
\hline & \multicolumn{3}{|c|}{ Fasting $(n=92)$} & \multicolumn{3}{|c|}{ Not Fasting $(\mathrm{n}=92)$} \\
\hline & $\begin{array}{l}< \\
\text { mean }\end{array}$ & $\geq$ mean & P Value & $<$ mean & $\geq$ mean & P Value \\
\hline \multicolumn{7}{|l|}{ Gender } \\
\hline $\begin{array}{l}\text { c. Male } \\
\text { d. Female }\end{array}$ & $\begin{array}{l}50,9 \\
42,9\end{array}$ & $\begin{array}{l}49,1 \\
57,1\end{array}$ & 0,594 & $\begin{array}{l}24,6 \\
42,9\end{array}$ & $\begin{array}{l}75,4 \\
57,1\end{array}$ & 0,109 \\
\hline \multicolumn{7}{|l|}{ Water Consumption } \\
\hline $\begin{array}{l}\text { a. }<\text { mean } \\
\text { b. } \geq \text { mean }\end{array}$ & $\begin{array}{l}50 \\
45\end{array}$ & $\begin{array}{l}50 \\
55\end{array}$ & 0,791 & $\begin{array}{l}35,7 \\
25\end{array}$ & $\begin{array}{l}64,3 \\
75\end{array}$ & 0,396 \\
\hline \multicolumn{7}{|l|}{ Body Mass Index } \\
\hline $\begin{array}{l}\text { c. Risk } \\
\text { d. Not Risk }\end{array}$ & $\begin{array}{l}48,5 \\
47,5\end{array}$ & $\begin{array}{l}51,5 \\
52,5\end{array}$ & 1.000 & $\begin{array}{l}37,5 \\
29,4 \\
\end{array}$ & $\begin{array}{l}62,5 \\
70,6 \\
\end{array}$ & 0,633 \\
\hline \multicolumn{7}{|l|}{ Physical Activity } \\
\hline $\begin{array}{l}\text { a. }<\text { mean } \\
\text { b. } \geq \text { mean }\end{array}$ & $\begin{array}{l}41,5 \\
56,4\end{array}$ & $\begin{array}{l}58,5 \\
43,6\end{array}$ & 0,229 & $\begin{array}{l}25 \\
40\end{array}$ & $\begin{array}{l}75 \\
60\end{array}$ & 0,191 \\
\hline \multicolumn{7}{|l|}{ Urine Density } \\
\hline $\begin{array}{l}\text { a. Several Dehydration } \\
\text { b. Mild Dehydration }\end{array}$ & $\begin{array}{l}30,8 \\
47,4\end{array}$ & $\begin{array}{l}69,2 \\
52,6\end{array}$ & 0,392 & $\begin{array}{l}66,7 \\
30,8\end{array}$ & $\begin{array}{l}33,3 \\
69,2\end{array}$ & 0,412 \\
\hline c. Well Hydrated & 51,7 & 48,3 & & 30,3 & 69,7 & \\
\hline
\end{tabular}

Based on table 5, it is known that the IST score when fasting is more than average and higher in men (75.4\%) compared to women. At the time of not fasting, it is known from the IST score that the urine density is above the average (69.7\%), which means that respondents are well hydrated. Likewise, during fasting, the urine density is above the average, which means that respondents are well hydrated $(51.7 \%)$.

Of all the variables analyzed statistically, it is known that the $p$ value $>0,005$. With the $p$ value $>\alpha(5 \%)$ it can be concluded that there is no significant relationship between gender, water consumption, urine density, and physical activity during fasting and not fasting and ITS score.

\subsection{Comparison of Differences between Water Consumption, Physical Activity, Body Mass Index, Urine Density, APM and IST Score When Fasting and Not Fasting}

T-Test statistical analysis was done to determine the difference between water consumption, physical activity, body mass index, urine density, and APM and IST score during fasting and not fasting, which is presented in Table 6 below. 
Table 6: Comparison of Differences between Water Consumption, Physical Activity, Body Mass Index, Urine Density, APM and IST Score When Fasting and Not Fasting

\begin{tabular}{|l|l|l|l|l|l|}
\hline & \multicolumn{2}{|l|}{ Fasting $(\mathrm{n}=92)$} & \multirow{2}{*}{ P value } & \multicolumn{2}{l|}{ Not Fasting $(\mathrm{n}=92)$} \\
& Mean & SD & & Mean & SD \\
Water consumption & 1467,2 & 690,2 & 0,004 & 1261,9 & 537,85 \\
Physical activity & 2,07 & 0,58 & 0,000 & 2,36 & 0,57 \\
\hline Body mass index & 20,71 & 4,34 & 0,320 & 20,70 & 4,33 \\
\cline { 1 - 2 } Urine Density & 1,017 & 0,013 & 0,022 & 1,013 & 0,008 \\
APM Score & 10,47 & 3,20 & 0,312 & 10,75 & 3,37 \\
IST Score & 106,38 & 11,55 & 0,000 & 112,98 & 15,19 \\
\hline
\end{tabular}

Based on table 6, it is known that the APM and ITS scores are higher at the time of not fasting if compared to when fasting, which are 10.75 and 112.98 . While the respondents' water consumptions are higher at the time of fasting if compared to when not fasting, which is 1467.2 $\mathrm{ml}$. Based on the statistical test, it is known that all variables but APM score and Body Mass Index, are have significant mean differences during fasting and not fasting by using $\alpha=5 \%$.

\subsection{The Relation of Dehydration as The mediator between gender, water consumption, physical activity and Memory (APM and IST)}

The figure 1 below shows the relation of dehydration as the mediator between gender, water consumption, physical activity and memory (APM and IST) without distinguishing fasting and not fasting conditions.

Figure 1: The Relation of Dehydration as The Mediator between Gender, Water Consumption, Physical Activity and Memory

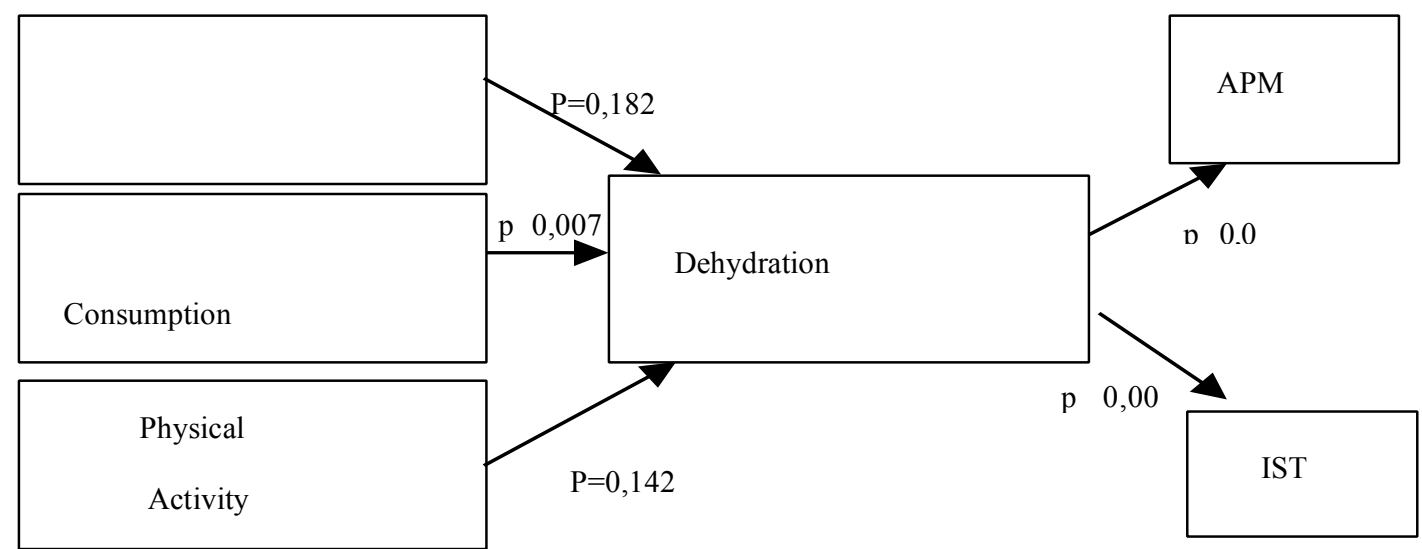


By using linear regression statistical test, it is known that the relationship between gender, water consumption, physical activity and dehydration are $0.182,0.007$, and 0.142 , as there are no statistically significant relationship between gender, water consumption, and physical activity and dehydration. Dehydration as the mediator variable between gender, water consumption, and physical activity, has the APM score of 0.000 and IST score of 0,000 , which means that dehydration do not act as a full mediator, but only as partial mediator. In other words there are other variables that are not examined in this study but affect the memory.

Independent and dependent variables of this study were taken during Ramadhan, which samples are consists of MAN 6 students, and furthermore, the independent and dependent variables from the University students were taken when Sunnah fasting (Monday and Thursday), thus it is known that the variable which affects the memory is the intention. [18] explained that the intention might sometimes predicts behavior with more accuracy, but does not provide much information about the reasons for such behavior to happen, thus a development of the Theory of Reasoned Action is needed. There are three constructs in the Theory of Planned Behavior, which are normative beliefs and subjective norms (in accordance with the Theory of Reasoned Action), also the additional constructs that is perceived behavioral control. This construct refers to understanding the ease or difficulty in displaying behavior, also assumed to be a reflection of past experience as an anticipation of obstacles and pitfalls. The more favorable an attitudes and subjective norms for a behavior and the better perceived behavioral control, the stronger it is for the individual to display the intention behaving under his or her consideration. In addition, the belief factor of fasting is likely to be better in samples which did Sunnah fasting. According to [18], there are three types of beliefs that are considered antecedent, which are the behavioral beliefs, that are assumed to affect attitudes toward behavior, normative beliefs that make up the basic determinants of subjective norms, and the control beliefs that form the basic perception of behavior control.

These beliefs may be based on past experiences towards behavior, but are usually influenced by second person's information about the behavior, through observation and notification from other person, or through other factors that increase or decrease perceptual difficulties in presenting questionable behavior.

The more sources and opportunities a person has, and the less one anticipates obstacles or difficulties, the better perceived behavioral control a person has towards behavior. In this aspect, belief means 'Ruhiyah' (awareness of spiritual relationship with Allah SWT), which convinced them to fast. For example, in Badar War, which won by Muslims in Ramadhan, implied that dehydration during fasting not really affecting the memory, because there is aspect such Ruhiyah which affects predominantly their belief about fasting.

In other words, when students are willing to volunteer as samples in this study, knowing the consequences of fasting, they have strong intention and belief in fasting. As their bodies are accustomed to fast, there is no effect of limiting the amount of water consumption to memory.

\subsection{The Pattern of Water Consumption by Time}

The table below shows the amount of water consumed when fasting and not fasting

Table 7: Amount of Water Consumption according to the Time when Fasting and not Fasting 


\begin{tabular}{|c|c|c|c|}
\hline $\begin{array}{l}\text { Total } \\
\text { Water } \\
\text { Consum } \\
\text { ed when } \\
\text { Fasting } \\
\text { (ml) }\end{array}$ & $\begin{array}{l}\text { Sahur water } \\
\text { consumption } \\
(\mathrm{ml})\end{array}$ & $\begin{array}{l}\text { Nightly } \\
\text { water } \\
\text { consumption } \\
\text { (ml) }\end{array}$ & \\
\hline 1,059 & 590 & 469 & \\
\hline $\begin{array}{l}\text { Total } \\
\text { Water } \\
\text { Consum } \\
\text { ed when } \\
\text { Not } \\
\text { Fasting } \\
\text { (ml) }\end{array}$ & $\begin{array}{l}\text { Morning } \\
\text { water } \\
\text { consumption } \\
(\mathrm{ml})\end{array}$ & $\begin{array}{l}\text { Afternoon } \\
\text { water } \\
\text { consumption } \\
(\mathrm{ml})\end{array}$ & $\begin{array}{l}\text { Nightly water } \\
\text { consumption } \\
(\mathrm{ml})\end{array}$ \\
\hline 1343 & 506 & 423 & 413 \\
\hline
\end{tabular}

The total average of water consumed by respondents during fasting $(1.059 \mathrm{ml})$ is less than the total average of water consumed by respondents when not fasting $(1,343 \mathrm{ml})$. If compared to the recommendation of Balanced Nutrition Guideline, where a person should consume water at least as much as $2000 \mathrm{ml}$ a day, the average of water consumed by respondents when fasting and not fasting only reached $50 \%$ of the Balanced Nutrition Guidelines's recommendations. Which means that the risk of dehydration when fasting and not fasting, based on the perspective of water consumption is just as great. Dehydration is the process of losing bodily fluid, which ultimately leads to hypohydration (water deficit condition). Acute dehydration symptoms may vary according to the weight loss. At $1-2 \%$ of weight loss, the feeling of thirst, weakness, fatigue, a little anxiety and loss of appetite will arise. Dry mouth, decreased amount of urine, and dry skin will occur at 3-4\% of weight loss. When body experienced 5-6\% of weight loss, it will cause difficulty in concentrating, headache, failure of body temperature control, and increase the breating frequency. $7-10 \%$ of weight loss can lead to Myalgia and collapse. Furthermore, $11 \%$ of weight loss will decrease blood volume, which may cause kidney failure [19].

Although there is no significant relationship between the consumption patterns and memory when fasting and not fasting, however, most of fasting samples are dehydrated than not fasting. When fasting, the average of respondent consumes more water during Sahür $(590 \mathrm{ml})$ than at night after Iftar $(469 \mathrm{ml})$. During Ramadhan, the opportunity to drink water is limited only at night from sunset until sunrise. When not fasting, the average water consumed in the morning tend to be more $(506 \mathrm{ml})$, if compared to the average water consumed during the day $(423 \mathrm{ml})$ and night $(413 \mathrm{ml})$. All Muslims who are already reached the sexual maturity (puberty), not in some specific circumstances (such as menstruating, pregnant and lactating mothers), and not mentally ill have to fast as commanded by Allah SWT in Al-Baqarah 2: 183-185, thus the limitation of water consumption should not be a barrier in fasting. Dehydration when fasting will not prevent someone to do a physical activity as the metabolism of the body at the time of fasting slows down, so it takes only a little water. There are less amount of food and drink consumed by a fasting person, thus the digestive tract, metabolism, the volume of urine and feces are decreases, the digestion system is rested and the energy of the body are used for the revitalization of the major organs, especially the liver and kidneys. Fasting is beneficial to health 
if done with a full spirit of fasting. The intact spirit characterized by doing fasting with sincerity and a well-controlled eat and drink. In the other hand, fasting without a well-controlled eat and drink at the time of Iftar will not improve the body's metabolic system [16].

By knowing the pattern of water consumption based on the time, there is water consumption setting recommended by researchers in order to not get dehydrated. The following table 8 shows example of recommendations of water consumption setting in a day when fasting so that the total of the water consumed in a day meets the recommendation of Balanced Nutrition Guidelines.

Table 8: Recommended Water Consumption Setting in a Day When Fasting

\begin{tabular}{|c|c|c|c|}
\hline Time & $\begin{array}{l}\text { Total Water } \\
\text { Consumed }\end{array}$ & $\begin{array}{l}\text { Household } \\
\text { Size }\end{array}$ & $\begin{array}{l}\text { Water } \\
\text { sources }\end{array}$ \\
\hline \multicolumn{4}{|l|}{ Sahūr } \\
\hline 03.00 & $250 \mathrm{ml}$ & $\begin{array}{l}11 / 4 \text { Cup } \\
\text { Medium } \\
\text { Glass }\end{array}$ & $\begin{array}{l}\text { Mineral } \\
\text { Water }\end{array}$ \\
\hline 03.30 & $200 \mathrm{ml}$ & $\begin{array}{l}1 \text { Cup } \\
\text { Medium } \\
\text { Glass }\end{array}$ & Tea \\
\hline 04.00 & $200 \mathrm{ml}$ & $\begin{array}{l}1 \text { Cup } \\
\text { Medium } \\
\text { Glass }\end{array}$ & $\begin{array}{l}\text { Mineral } \\
\text { Water }\end{array}$ \\
\hline \multicolumn{4}{|c|}{ Iftar-Night } \\
\hline 18.00 & $200 \mathrm{ml}$ & $\begin{array}{l}1 \text { Cup } \\
\text { Medium } \\
\text { Glass }\end{array}$ & $\begin{array}{l}\text { Mineral } \\
\text { Water }\end{array}$ \\
\hline 18.30 & $400 \mathrm{ml}$ & $\begin{array}{l}2 \text { Cup } \\
\text { Medium } \\
\text { Glass }\end{array}$ & $\begin{array}{l}\text { Mineral } \\
\text { Water }\end{array}$ \\
\hline 19.00 & $200 \mathrm{ml}$ & $\begin{array}{l}1 \text { Cup } \\
\text { Medium } \\
\text { Glass }\end{array}$ & Tea \\
\hline 20.30 & $400 \mathrm{ml}$ & $\begin{array}{l}2 \text { Cup } \\
\text { Medium } \\
\text { Glass }\end{array}$ & $\begin{array}{l}\text { Mineral } \\
\text { Water }\end{array}$ \\
\hline 21.30 & $200 \mathrm{ml}$ & $\begin{array}{l}1 \text { Cup } \\
\text { Medium } \\
\text { Glass }\end{array}$ & Milk \\
\hline
\end{tabular}

\section{Conclusion}

All of the fasting samples were dehydrated if compared to those who are not fasting. The results of this study support the results of previous studies where when fasting, the average respondent 
consumes less water than when not fasting, which results are that most of them who were fasting were dehydrated.

All Muslims who are already reached the sexual maturity (puberty), not in some specific circumstances (such as menstruating, pregnant and lactating mothers), and not mentally ill have to fast, thus the limitation of water consumption should not be a barrier in fasting. Fasting is beneficial to health if done with a full spirit of fasting. The intact spirit characterized by doing fasting with sincerity (intention and belief) and a well-controlled eat and drink. Based on this study, it is known that there is no significant relationship between the patterns of water consumptions and memory when fasting and not fasting. The aspects of intentions and beliefs of fasting was suspected as the force underlied the fasting behavior, thus although respondents were dehydrated, it will not disrupt the cognitive function, especially the short-term memory.

\section{References}

[1]Environment Canada. 2012. Your Very Own Body Water. Available at http://www.ec.gc.ca/eauwater/default.asp?lang=En\&n=B97AED14-1. (accessed 11 March 2012).

[2]The Health Department of Republic of Indonesia. 2002. Pedoman Umum Gizi SeimbangRepublic of Indonesia.. Jakarta : The Health Department of The

[3]Danone Institute Foundation. 2002. Sehat Bugar Berkat Gizi Seimbang, Kompas Gramedia.

[4]Santoso, et al. 2011. Air Bagi Kesehatan. Centra Communications.

[5]Manz, F. 2007. Hydration and disease. J Am Coll Nutr, Okt;26 (5 Suppl) :535S-41S.

[6]Gopinathan, PM et al. 1988. Role of dehydration in heat stressinduced variations in mental performance. Arch Environ Health. Vol 43, pp 15-17

[7]WGBH educational foundation. 2012. Discovering psychology: Human Brain. http://www.learner.org/discoveringpsychology/brain/brain flash.html accessed on March 11,2012

[8]Society for Neuroscience. 2007. The Adolescent Brain. Brain Briefings. Available at http://www.sfn.org/index.aspx?pagename=brainBriefings Adol escent brain . (accessed 11 Maret 2012).

[9] Deary, I. J et al. 2007. Intelligence and educational achievement. Intelligence. Vol 35. pp $13-21$

[10]Kusrohmaniah, S. 2008. Neurophysiology Memory. Buletin Psikologi vol.16,no.2,103-110. ISSN:0854-7108.

[11]Hardinsyah et al. 2010. Kebiasaan Minum dan Status Dehidrasi pada Remaja dan Dewasa di Beberapa Daerah di Indonesia-THIRST. PERGIZI PANGAN Indonesia, FEMA IPB, FKM UNAIR dan FKM UNHAS.

[12]Grandjean, A.C. and Grandjean N.R. 2007. Dehydration and cognitive performance. J Am Coll Nutr. Vol. 26:549S-554S.

[13]Thobroni, M. 2010. Aku Puasa Maka Aku Kaya, Jogyakarta: Bintang Pustaka.

[14]Syahirul, A.A. 2010. Keajaiban Puasa Sunah. Jakarta Pusat: Belanoor.

[15]Al-Zuhayly, W. 2005. Puasa dan Itikaf. Bandung: Remaja Rosdakarya.

[16]Kazemi, M., Nematy, M., Norouzy, A., Amini, M., Mohajeri, S.A., Razavi, A. 2013. Ramadan Fasting: Evidence or Expert Opinion? Results of Preliminary Studies. J Fasting Health. Vol.1(2):58-65. 
[17] Hardinsyah, et al. 2009. Kebiasaan minum dan status dehidrasi pada Remaja dan Dewasa. Makalah pada Seminar Air Bagi Kesehatan. Unpublished Manuscript, PERGIZI PANGAN Indonesia dan FEMA IPB. Bogor.

[18]Crano, W., Prislin, R. 2011. Attitudes and Attitude Change. Psychology Press.

[19]Pruvost, I., Dubos, F., Chazard, E., Hue, V., Duhamel, A., Martinot, A. 2013. The Value of Body Weight Measurement to Assess Dehydration in Children. PLoS ONE Vol. 8(1): e55063. https://doi.org/10.1371/journal.pone.0055063 